\title{
Workshops: Appropriate Strategies for Promotion of Functional Garments
}

\author{
Neelam Pruthi*, Chanchal and P. Seetharaman \\ Department of Clothing and Textiles, College of Home Science, CCS Haryana Agricultural \\ University, Hisar 125 004, Haryana, India \\ *E-mail:neelam_pruthi@yahoo.co.in
}

KEYWORDS Functional. Garments. Information. Workshops

\begin{abstract}
In a study, functional features were recommended for garments of children using calipers and crutches, upper limb amputees, lower limb amputees, hemiplegics and paraplegics after trials of the garments designed for them in accordance to their clothing related problems. To promote functional garments amongst the target group, their construction and production was initiated. For that a catalogue entitled 'Drafting Technique of Functional Garments' was prepared in English and Hindi. To impart technical know how regarding functional garments, workshops were organized in two rehabilitating organizations running training-cum production center. The workshops were attended by the instructors and the trainees of the centers including handicapped persons. The participants had high opinion about the functional garments because they found that 'The functional features incorporated in the garments will increase their serviceability and durability', 'the functional garments will enhance the personality of the wearer' and 'the functional garments will reduce the dependency of the disabled on the caretakers'. The workshop was found highly useful as they felt that the workshop would prove to be a boon in their life because they learnt to develop design of garments for persons with different disabilities and also acquired sufficient skill to stitch the functional garments.
\end{abstract}

\section{INTRODUCTION}

Number of government and non-government organizations are working for rehabilitation of the disabled. Removal of feeling of inadequacy and inferiority, restoration of confidence and a spirit of independence are the most important aims of rehabilitation. Clothing is also one of the rehabilitating tools for the handicapped as it facilitates and encourages independent dressing and undressing and boost up their self-esteem which also need special attention. The clothing related problems of the disabled are highly individualized because these depend on the type of disability. It is a matter of frustration for the caretakers to find clothes that meet the requirements of their physically disabled wards in an era geared to mass production and standardization. The clothing related problems are left to parents, which are not easy to be solved because of the reason that disabled need clothing that fit their body which is not of standard size or shape. Few of them need garments with plackets which can be reached easily with manipuable fasteners that can be operated with limited arm movements while others need reinforcement at specific areas. (Friends et al.1973)

To cater to needs of the handicapped with different type of disabilities a study was conducted to design functional garments for them The problems of the selected respondents were crtically analyzed and suitable garments were designed in accordance to their requirements. On the basis of suitability assessment (functional features were recommended for the garments of calipers and crutches users (Pruthi et al. 2001, 2004b), upper and lower limb amputees (Pruthi et al. 2001, 2002, 2004a, c), hemiplegics (Pruthi et al. 2003) and paraplegics (Pruthi et al. 2005, 2006).

During study it was observed that by developing suitable garment designs as per the specific needs of the disabled will be of no use until and unless their information reaches to the beneficiaries. It was also analyzed that for popularization and wider adoption of functional garments, their production must be initiated in tailoring-cum-production centers being run by the rehabilitating organization which can only be possible if the persons engaged in cutting and tailoring has knowledge about the modifications required to be made while drafting and cutting. Therefore an endeavour was made to impart technical know by organizing workshops in the production centers being run by rehabilitation organizations. Opinion of the participants regarding functional garments as well workshop has been highlighted in the present paper.

\section{METHODOLOGY}

To design functional garments for the disabled the study was conducted in three phases 
Phase-I: Two hundred respondents, comprising children using caliper and crutches, upper limb amputees, lower limb amputees, hemiplegics and paraplegics were selected. To identify their clothing related problems, interview and observation techniques were used.

Phase-II: Functional features were incorporated in the most commonly used garments of the selected categories of disabled to overcome their clothing related problems. The functional garment were tried to assess their suitability for recommendations of functional features.

Phase-III: To disseminate the information regarding suitable functional garment to the target group, catalogues of draftings were prepared. To impart technical know-how regarding stitching of functional garments, workshops were organized in two rehabilitating organizations namely Amar Jyoti cheritable trust, Karkarduma, Delhi and Haryana Saket council, Chandimandir, Haryana which were running training-cum-production centers.

The workshops were attended by 23 participants including instructors and trainees and among them many of them were handicapped persons. Opinion statements were formulated to develop two opinion schedules to seek the opinion of the participants regarding workshop and functional garments which was sought on three point scale: agree, somewhat agree and disagree scoring 2, 1 and zero. Weighted mean score was calculated to draw the inferences.

\section{RESULTSAND DISCUSSION}

During workshops the participants were given lecture-cum-demonstration and were imparted technical know-how about drafting, cutting and stitching of functional garments. Type of garments taught to each participant was according to their potentials.

Analysis of the opinion of the participants was sought regarding functional garments as well as workshop and its analysis has been presented as follow.

\section{Participants' Opinion Regarding Functional Garments}

It is evident from the data (Table 1) that maximum number of respondents agreed with the statement that 'functional features incorporated in the functional garments will increase their durability and serviceability' and 'it is worth spending extra money on functional garments' scoring highest (1.90),' followed by use of functional garments will reduce the burden on caretakers' (1.83)'functional garments will camouflage the disability' (1.70), 'the wearer can attend any social gathering with functional garments' (1.4).

There were many respondents who did not agree with the following statements because majority of the respondents disagreed with these: 'The functional garments are not good to look at' (0.3) 'the wearer will look different from the

Table 1: Participants; opinion regarding functional garments

\begin{tabular}{|c|c|c|c|c|c|}
\hline $\begin{array}{l}\text { S. } \\
\text { No }\end{array}$ & Statements & Agree & $\begin{array}{l}\text { Some } \\
\text { what agree }\end{array}$ & Disagree & W.M.S \\
\hline 1. & $\begin{array}{l}\text { Functional garments will Camouflage (hide) } \\
\text { the disability of the wearer. }\end{array}$ & 17 & 5 & 1 & 1.7 \\
\hline 2 . & $\begin{array}{l}\text { Use of functional garments will reduce the } \\
\text { dependency of the wearer on caretaker }\end{array}$ & 19 & 3 & 1 & 1.83 \\
\hline 3 . & $\begin{array}{l}\text { These garment will take more time of the wearer/ } \\
\text { caretaker as compared to existing dresses }\end{array}$ & 19 & 1 & 13 & 0.83 \\
\hline 4. & $\begin{array}{l}\text { The functional features incorporated in the } \\
\text { garment will increase their serviceability and durability }\end{array}$ & 22 & - & 1 & 1.92 \\
\hline 5. & $\begin{array}{l}\text { The wearer will look different from normal after } \\
\text { wearing functional garments }\end{array}$ & - & 4 & 19 & 0.34 \\
\hline 6. & It is worth spending extra money on functional garments & 21 & 2 & - & 1.92 \\
\hline 7. & The functional garments are not good to look at & 1 & 5 & 17 & 0.30 \\
\hline 8 . & These garments will enhance the personality of the wearer & 20 & 3 & - & 1.90 \\
\hline 9. & $\begin{array}{l}\text { The wearer can attend any social } \\
\text { gathering with functional garments }\end{array}$ & 20 & 1 & 2 & 1.40 \\
\hline 10 . & $\begin{array}{l}\text { The maintenance, care and renovation of functional } \\
\text { garment is difficult as compared to existing dresses }\end{array}$ & 10 & 4 & 9 & 1.04 \\
\hline 11. & $\begin{array}{l}\text { There is no use of these garments as these are not } \\
\text { going to help persons with disability }\end{array}$ & 3 & 2 & 18 & 0.44 \\
\hline
\end{tabular}


normal one after wearing functional garments' $(0.34)$ and 'there is no use of these garments as these are not going to help persons with disability' (0.44).

The findings of the present study was in conformity with the finding of Ahrbeck and Friend (1976) who also reported that handicapped had difficulty in obtaining appropriate clothes as per their body size. Attractive clothing helped in development of higher self-concept by giving the handicapped confidence in their appearance.

\section{Participant's Opinion for the Workshop on Functional Garments}

Data pertaining to opinion of the participants regarding workshop on functional garments has been presented in Table 2. The data elucidated that maximum number of the respondents opined: This workshop will prove to be a boon in my life' and 'the facilitator has in-depth knowledge regarding clothing related problems of the disabled' scoring highest in each case (1.92). Other statements scoring in descending order were 'this workshop has given me an idea to probe more about clothing related problems encountered by the physically handicapped' (1.9). 'The workshop has helped me to suggest many other designs for the persons having physical disabil- ity' (1.83), 'I will continue to stitch these garments if I get the opportunity' (1.74). and 'I have acquired sufficient skill to stitch the functional garments taught to me' (1.62).

Following statements score very low as maximum number of respondents disagreed with these: 'Due to complicated design I do not like to stitch these garments' $(0.43)$ followed by 'Workshop was just a wastage of time' $(0.26)$, 'this workshop has not imparted sufficient knowledge to deal with clothing related problems of different categories of physically handicapped' (0.22).

The participants also appreciated the catalogue prepared on drafting technique of functional garments. Later on the catalogue so prepared was sponsored by LIONS club for publication in the form of book.

Lamb (1984) reported that an advance course was planned for undergraduate students with an objective to prepare them to understand the special clothing needs of the physically handicapped, disabling conditions that create clothing or dressing problems. Koster and Leber (1984) found that majority of the physically handicapped preferred to obtain clothing information from catalogue, family magazines, news papers, pamphlets, news letters, television and extension bulletins.

Table 2: Participants' opinion about workshop on functional garments.

\begin{tabular}{|c|c|c|c|c|c|}
\hline $\begin{array}{l}\text { S. } \\
\text { No }\end{array}$ & Statements & Agree & $\begin{array}{l}\text { Some } \\
\text { what agree }\end{array}$ & Disagree & W.M.S. \\
\hline 1 . & $\begin{array}{l}\text { This workshop has given me an idea to probe more about the } \\
\text { clothing related problems encountered by the } \\
\text { physically handicapped }\end{array}$ & 20 & 3 & - & 14 \\
\hline 2 . & $\begin{array}{l}\text { I have acquired sufficient skill to stitch the functional garments } \\
\text { taught to me }\end{array}$ & 15 & 7 & 1 & 1.62 \\
\hline 3. & $\begin{array}{l}\text { This workshop has not imparted sufficient knowledge to deal } \\
\text { with clothing related problems of different categories of } \\
\text { physically handicapped. }\end{array}$ & 2 & 8 & 13 & 0.52 \\
\hline 4. & I will continue to stitch these garments, if I get the opportunity & 19 & 2 & 2 & 1.74 \\
\hline 5 . & $\begin{array}{l}\text { The workshop has helped me to suggest many other designs for } \\
\text { the persons having physical disability }\end{array}$ & 19 & 4 & - & 1.83 \\
\hline 6. & $\begin{array}{l}\text { I have acquired sufficient skill to start my enterprise to cater } \\
\text { to the needs of functional garments of any organization }\end{array}$ & 11 & 6 & 6 & 1.2 \\
\hline 7. & Due to complicated designs, I do not like to stitch these garments & 3 & 4 & 16 & 0.43 \\
\hline 8. & This workshop was just a wastage of time and money & 2 & 2 & 21 & 0.26 \\
\hline 9. & $\begin{array}{l}\text { Duration of workshop was not sufficient to learn designing } \\
\text { and stitching of functional garments for different } \\
\text { categories of disabled persons }\end{array}$ & 10 & 5 & 8 & 1.1 \\
\hline 10 . & $\begin{array}{l}\text { The facilitator has indepth knowledge regarding clothing } \\
\text { related problems of the disabled }\end{array}$ & 21 & 2 & - & 1.92 \\
\hline 11. & This workshop will prove to be a boon in my life & 21 & 2 & - & 1.92 \\
\hline
\end{tabular}




\section{CONCLUSION}

From the study it can concluded that participants of the workshop who were taught cutting and stitching of functional garments were also of the view that functional garments would be very useful for the disabled as these garments would last longer, camouflage the disability, will enhance the personality and reduce the dependency of the disabled on the caretakers. The workshop was also found to be useful as they learnt to design garments for persons with different disabilities, acquired sufficient skill to stitch different type of functional garments and they decided to continue stitching of functional garments to earn their livelihood and help the disabled.

\section{RECOMMENDATIONS}

Many more such workshops must be organized to train the persons for designing cutting and stitching of functional garments

Print and electronic media should be prepared to disseminate the knowledge to the target group

NGO's must come forward for organization of such workshop for popularization of functional garments for rehabilitation of the disabled.

\section{REFERENCES}

Ahrbeck E, Friend SE 1976. Clothing - An Asset or Liability Designing for Specialized Needs Rehabilitation Literature, 37(10): 295-296.

Friend SE, Zaccaaginine J, Suffivan M 1973. Meeting the clothing needs of handicapped children. $J$ Home Eco, 63(5): 25-27

Koester AW, Leber DA 1984. Diffusion of Information about Clothing to Orthopaedically Disabled Adults. Home Eco Res J, 13: 153-158.

Lamb J M 1984. Clothing for the physically disabled and elderly: An instructional approach. J Home Eco, 76(4): 23-25

Pruthi N, Seetharaman P, Chanchal 2001.Easy to wear Garments for Men With Upper Amputated Limbs. Journal of Family Ecology, 3(2):110-113

Pruthi N 2001.Viklango Ke Liye Kiryasheel Vastro Ki drafting avm Katai Ki Vidhi (in Hindi). Haryana: Gaurav Society of ARIC, Hisar.

Pruthi N, Seetharaman P, Chanchal 2002.Clothing Related Problems Encountered by Lower Limb Amputees. Journal of Family Ecol, 4(1\&2): 224-226

Pruthi N, Singh Jeet SS, Punia S 2003 Acceptance of Functional Garments for the Disabled. Journal of Family Ecol, 4(1\&2): 180-182

Pruthi N, Seetharaman P, Chanchal 2003. Problems Encountered by Hemiplegics While Dressing and Undressing. J Hum Ecol, 14(6):463-465

Pruthi N, Seetharaman P, Chanchal 2004a. Functional Garments for Men with Lower Amputated Limb. $J$ Hum Ecol, 15(1):41-44

Pruthi N, Chanchal, Seetharaman P 2004b. Functional Clothes for the Calipers and Crutches Users. Proceedings of National Seminar on Functional Clothing and Social Integration of the Handicapped, Deptt. of Clothing and Textiles. COHS, CCS Haryana Agricultural University,Hisar, Haryana

Pruthi N, Seetharaman P, Chanchal 2004c. Problems Encountered While Dressing and Undressing by Persons with Upper Amputated Limb. J Soc Sci, 9(2): 91-93.

Pruthi N, Seetharaman P, Chanchal 2005. Clothing Related Problems Encountered by Paraplegics. J Hum Ecol,17(1): 59-61

Pruthi N, Chanchal, Seetharaman P 2006. Protective Clothing for Paraplegic Women. J Hum Ecol, 19(4): 267-271. 